\title{
PEMBELAJARAN FILOLOGI SEBAGAI SALAH SATU UPAYA DALAM MENGUNGKAP DAN MEMBANGUN KARAKTER SUATU BANGSA
}

\author{
Trie Utari Dewi \\ Universitas Muhammadiyah Prof. DR. HAMKA \\ trie.utarid@gmail.com
}

\begin{abstract}
ABSTRAK
Tujuan penelitian ini adalah untuk mengetahui pentingnya peran filologi dalam membangun karakter bangsa yaitu dengan cara menggali nilai-nilai moral dan karakter bangsa melalui penelitian atau penggarapan terhadap naskah-naskah, baik yang yang telah diteliti maupun yang belum dianalisis oleh para filologi. Metode yang digunakan dalam penelitian ini adalah metode deskrptif analitik dengan pendekatan kualitatif. Adapun hasil yang diperoleh dari penelitian ini adalah manfaat dari pembelajaran filologi di antaranya yaitu memahami kebudayaan suatu bangsa, terungkapnya kebiasaan masyarakat dan adat istiadat orang-orang terdahulu, serta terungkapnya sejarah suatu bangsa yang sesungguhnya. Dengan terungkapnya kebudayaan, adat istiadat, dan sejarah di masa lampau, maka akan terungkap pula identitas dan karakter suatu bangsa. Salah satunya yaitu melalui penggarapan terhadap naskah Anis Al-Muttaqin dan Naskah Siksakandang Karesian, yang di dalamnya terkandung nilai moral dan karakter yang seharusnya dimiliki oleh seorang pemimpin. Kesimpulan daalam memahami nilai perilaku manusia yang berhubungan dengan Tuhan, diri sendiri, sesama manusia dan lingkungan perlu adanya pembelajaran filologi berupa naskah. Sehingga muncul nilai yang terkandung dalam naskah untuk mengembalikan karakter bangsa.
\end{abstract}

Kata Kunci: Karakter, Pembelajaran Filologi

\begin{abstract}
The aim of the research to know, the importance of the role of philology in building the character of the nation that is by digging the moral values and character of the nation through research or cultivation of manuscript, both those that have been studied and that have not been analyzed by the philologists.The method used in this research is descriptive analytic method with qualitative approach. The results obtained from this study is the benefits of philology learning among which is to understand the culture of a nation, the unfolding of habits and customs of the people of the past, and the disclosure of the history of a real nation. With the unfolding of culture, customs, and history in the past, it will reveal the identity and character of a nation. One of them is through the cultivation of the text Anis Al-Muttaqin and Siksakandang Karesian script, in which contained moral values and character that should be owned by a
\end{abstract}


leader.Conclusions In understanding the value of human behavior related to God, self, fellow human beings and the environment there is a need for philological learning in the form of texts. So that the value contained in the text appears to restore the nation's character.

Keywords: Character, Philology Study

\section{PENDAHULUAN}

Maraknya kasus korupsi yang terjadi belakangan di negara Indonesia menunjukkan masih banyaknya perilaku tidak jujur para pemimpin negara ini. Selain itu, kasus pembakaran rumah-rumah ibadah dan pengusiran atau pembunuhan atas agama tertentu juga membuktikan bahwa masih kurangnya toleransi yang terjadi di kehidupan masyarakat. Ditambah lagi kasus-kasus perselingkuhan yang melibatkan aparatur negara.

Hal ini menunjukkan kurangnya moral baik yang tertanamkan dalam diri seseorang. Alasan mengapa masalah moral menjadi persoalan penting dalam sejarah kehidupan manusia sejak zaman dahulu sampai dengan sekarang yaitu: 1) secara eksistensial, manusia adalah makhluk berakal (homo sapiens).

Sebagai makhluk berakal, dalam realitasnya, manusia mewujud sebagai sosial (homo socius)_yang memiliki fitrah (natural endowment) yang secara alamiah harus mengada bersama orang lain. Untuk menjaga, memelihara, menertibkan relasi di antara makhluk sosial ini, secara normatif diperlukan tatanan berupa norma sopan santun, norma moral, dan norma hukum; 2) perdebatan yang terjadi ikhwal "dari mana sumber nilai moral, siapa yang berotoritas penuh dan absah untuk merumuskan "moral judgment" nilai moral dan bagaimana skala keberlakuan nilai moral itu sendiri masih berlangsung sengit hingga kini (Yusuf, 2013).

Permasalahan

korupsi, kekerasan, pembunuhan, tawuran, pemerkosaan, dan lain sebagainya telah membuat masyarakat semakin resah. Ditambah lagi dengan jawabanjawaban yang dilontarkan oleh para pemimpin saat ini yang dirasa tidak bijaksana oleh rakyatnya atas permasalahan-permasalahan bangsa yang terjadi.

Sehingga jawaban-jawaban tersebut yang seharusnya dapat menjadi solusi namun malah menambah masalah dan keresahan bagi masyarakat. Akan dibawa ke mana kelak negara ini jika pemimpin dan generasinya terus seperti itu? Sikap ramah, jujur, dan saling menghormati yang merupakan ciri khas bangsa Indonesia yang multikultural kini perlahan luntur dan musnah dikarenakan permasalahanpermasalah tersebut.

Lalu, bagaimana caranya agar jati diri dan karakter bangsa ini tidak semakin terkikis dan musnah? dimana saat ini sulitnya mencari figur atau sosok yang dapat dijadikan contoh bagi para pemimpin maupun 
masyarakat dan para penerus generasi bangsa. Berdasarkan hal tersebut, perlu adanya upaya yang sungguhsungguh dalam membangun kembali karakter bangsa Indonesia.

Pembelajaran filologi merupakan salah satu upaya untuk dapat mengungkap informasi tentang kehidupan masyarakat di masa lampau, baik mengenai sejarahnya, adat istiadat, maupun pemikiran dan hasil karyanya, yang tersimpan dalam bentuk peninggalan tertulis atau disebut sebagai naskah kuno/lama. Namun, untuk dapat mengetahui isi dari sebuah naskah diperlukan kemampuan dalam memahami bahasa serta aksara yang digunakan dalam naskah tersebut. Akan tetapi, saat ini hanya sedikit sekali yang dapat memahami bahasa dan aksara yang terdapat dalam naskah Nusantara.

Hal ini dikarenakan bahasa dan aksara yang digunakan dalam naskah adalah bahasa serta aksara yang tidak biasa digunakan oleh masyarakat umum dalam kehidupan sehari-hari pada masa kini. Bahasa tersebut adalah bahasa Arab, Melayu, Sunda, Jawa, Bali, dll. Sedangkan aksaranya adalah aksara pegon, Arab, jawa kuno, maupun sunda kuno.

Dikarenakan kendala tersebut, maka banyak orang yang tidak tertarik untuk membaca dan mengetahui isi dalam naskah, ditambah lagi dengan kesibukan para ahli filologi yang banyak menghabiskan waktu dan lebih mementingkan suntingan naskah dan kritik teks, sehingga membuat filologi semakin ketinggalan zaman dan tidak terungkap nilai-nilai penting yang terkandung di dalamnya. Padahal, kajian filologi Indonesia haruslah kosmopolitan, sekuler, dan modern (Sudibyo, 2007).

Berdasarkan hal tersebut, maka diperlukan pemahaman mendalam mengenai pembelajaran filologi agar dapat menghasilkan penggarapan naskah yang tidak hanya terfokus pada suntingan naskah dan kritik teks saja, tetapi juga pengungkapan nilai-nilai dan kandungan yang terdapat dalam naskah tersebut. Adapun penelitian sebelumnya yang membahas tentang ilmu filologi adalah pada pidato pengukuhan Guru Besar ilmu filologi di Universitas Sebelas Maret Surakarta oleh Bani Sudardi pada tahun 2007 yang berjudul Sumbangan Filologi dalam Penyusunan Strategi Kebudayaan Indonesia.

Akan tetapi, penelitian tersebut hanya membahas tentang ilmu filologi dan sumbangannya dalam strategi kebudayaan Indonesia. Sedangkan dalam penelitian ini, penulis akan menguraikan tentang proses pembelajaran filologi dan mengungkap tentang manfaat dan perannya dalam membangun karakter bangsa.

Ilmu filologi berusaha untuk menemukan teks asli atau mendekati asli dan menempatkannya dalam seluruh aspek sejarah suatu bangsa, yaitu dengan cara melakukan penggarapan terhadap naskah. Filologi yang menitikberatkan penelitiannya kepada hal tersebut disebut filologi tradisional, adapun filologi modern memandang naskah sebagai dokumen 
budaya yang merupakan refleksi dari zamannya.

Dengan kata lain, karakter suatu bangsa dapat dibangun dengan cara mengetahu identitas suatu bangsa, dan tidak lepas dari sejarah bangsa yang dapat diungkap melalui proses pembelajaran filologi. Sebagaimana yang dinyatakan oleh Bachtiar (dalam Suryani, 2012) bahwa sebagian besar sejarah dapat diangkat kembali melalui pengetahuan filologi. Pengetahuan bangsa Indonesia terhadap sejarah akan memperkuat kebudayaan yang dikembangkannya dan juga makin memperkuat identitas kebangsaannya. Oleh karena itu, studi filologi/pembelajaran filologi sangat penting dan besar bantuannya demi membangun karakter suatu bangsa.

\section{METODE PENELITIAN}

Metode yang digunakan dalam penelitian ini adalah metode deskriptif analitik dengan pendekatan kualitatif, yaitu dengan cara menguraikan tentang pentingnya pendidikan karakter, pembelajaran filologi, dan proses penggarapan naskah yang merupakan objek kerja filologi. Lalu dari uraian tersebut dianalisis hal-hal yang dapat dijadikan penguat bagi pembangunan karakter bangsa.

Adapun jenis penelitian yang digunakan yaitu studi literatur. Metode studi literatur adalah serangkaian kegiatan yang berkenaan dengan metode pengumpulan data pustaka, membaca dan mencatat, serta mengolah bahan penelitian (Zed dalam Kartiningrum, 2015).
Adapun data penelitian yang digunakan berasal dari jurnal, artikel ilmiah, dan buku mengenai filologi serta naskah yang berisikan tentang nilai-nilai moral yang dapat membangun karakter suatu bangsa.

\section{HASIL DAN PEMBAHASAN Pendidikan Karakter}

Pendidikan karakter dapat dipahami sebagai upaya yang dirancang dan dilaksanakan secara sistematis dan terencana untuk membantu peserta didik memahami nilai-nilai perilaku manusia yang berhubungan dengan Tuhan Yang Maha Esa, diri sendiri, sesama manusia, lingkungan, dan kebangsaan yang terwujud dalam pikiran, sikap, perasaan, perkataan, serta perbuatan berdasarkan norma-norma agama, hukum, tata krama, budaya, dan adat istiadat (dalam Johansyah, 2011). Untuk dapat memahami nilai-nilai tersebut, menekankan pentingnya tiga komponen karakter yang baik (components of good character), yaitu moral knowing atau pengetahuan tentang moral, moral feeling atau perasaan tentang moral, dan moral action atau perbuatan moral.

Hal ini diperlukan agar anak mampu memahami, merasakan dan mengerjakan sekaligus nilai-nilai kebijakan (dalam Citra, 2012). Adapun nilai-nilai pendidikan karakter yang dikembangkan oleh Kemendikbud (Kementerian Pendidikan dan Kebudayaan) ada delapan belas karakter.

Nilai-nilai tersebut bersumber dari agama, Pancasila, budaya, serta 
tujuan pendidikan nasional. Delapan belas nilai tersebut yaitu: religius, jujur, toleransi, disiplin, kerja keras, kreatif, mandiri, demokratis, rasa ingin tahu, semangat kebangsaan, cinta tanah air, menghargai prestasi, bersahabat/komunikatif, cinta damai, gemar membaca, peduli lingkungan, peduli sosial, dan tanggung jawab (Maunah, 2015). Nilai-nilai tersebut sesungguhnya telah ada dalam jati diri bangsa Indonesia sejak lama.

Pendidikan karakter pada intinya bertujuan membentuk bangsa yang tangguh, kompetitif, berakhlak mulia, bermoral, bertoleran, bergotong royong, berjiwa patriotik, berkembang dinamis, serta berorientasi pada ilmu pengetahuan dan teknologi yang semuanya dijiwai oleh iman dan takwa kepada Tuhan yang Maha Esa berdasarkan Pancasila. Pendidikan karakter berfungsi mengembangkan potensi dasar agar berhati baik, berpikiran baik, dan berperilaku baik; (2) memperkuat dan membangun perilaku bangsa yang multikultur; (3) meningkatkan peradaban bangsa yang kompetitif dalam pergaulan dunia (Kementerian Pendidikan Nasional dalam Johansyah, 2011).

\section{Pembelajaran Filologi}

Menurut Baried (dalam Suryani, 2012) filologi dalam arti yang luas adalah ilmu yang menyelidiki perkembangan kerohanian suatu bangsa dan kekhususannya atau menyelidiki kebudayaan berdasarkan bahasa dan kesusastraannya. Berdasarkan hal tersebut, dapat dinyatakan bahwa melalui kegiatan studi filologi dapat terungkap pemikiran-pemikiran orang-orang terdahulu, tidak hanya nilai, norma, dan ajaran agamanya, tetapi juga kebudayaan, adat istiadat, serta sejarahnya.

Adapun filologi sebagai istilah mempunyai beberapa arti sebagai berikut: 1) filologi berarti ilmu pengetahuan tentang segala sesuatu yang pernah diketahui orang; 2) filologi pernah dipandang sebagai sastra secara ilmiah; 3) filologi dipakai juga sebagai untuk menyebut studi bahasa atau ilmu bahasa (linguistik); dan 4) filologi ialah suatu disiplin yang mendasarkan kerjanya pada bahan tertulis dan bertujuan mengungkapkan makna teks tersebut dalam segi kebudayaan (Baried dkk, 1985). Berdasarkan pengertianpengertian tersebut, dapat dikatakan bahwa filologi bukan hanya dipandang sebagai pintu gerbang kehidupan masa lampau, tetapi juga pintu gerbang berbagai ilmu pengetahuan yang dapat diketahui melalui naskah.

Studi filologi dalam menyajikan teks seperti suntingan naskah yang disertai catatan berupa aparat kritik, kajian bahasa naskah, singkatan isi naskah, bahasa teks, dan terjemahan teks ke dalam bahasa nasional ataupun bahasa internasional, berperan sebagai ilmu bantu bagi disiplin ilmu lainnya. Mengingat bahwa kandungan naskah itu beraneka ragam maka filologi dapat membantu berbagai ragam ilmu. Beberapa di antaranya ialah linguistik, ilmu sastra, ilmu sejarah, sejarah kebudayaan, ilmu hukum adat, ilmu 
agama, dan ilmu filsafat (Baried dkk, 1985).

Pentingnya ilmu filologi telah terlihat sejak masa Yunani lama. Di mana ilmu filologi digunakan untuk menyajikan kebudayaan Yunani lama yang tertuang dalam naskah yang dimilikinya. Kebudayaan tersebut sangat berperan dalam memperluas dan memperdalam pengetahuan mengenai sumber dari segala ilmu pengetahuan dan berpengaruh tidak hanya di dunia Barat, tetapi juga di kawasan Timur Tengah, Asia, sampai kepada kawasan Nusantara. Di Eropa sendiri, isi-isi naskah yang merupakan penggarapan dari ilmu filologis telah banyak mewarnai dunia pendidikan.

Sedangkan di kawasan Timur Tengah, teori filologi digunakan untuk menelaah naskah-naskah Yunani dan naskah-naskah yang dihasilkan oleh penulis-penulis dari daerah itu, karena bangsa-bangsa di Timur tengah dikenal sebagai bangsa yang memiliki dokumen lama yang bernilai agung. Adapun studi filologi di kawasan Asia terhadap naskah-naskah yang dimiliki telah berhasil membuka khazanah kebudayaan Asia serta telah menyajikan isi naskah-naskah tersebut untuk kepentingan studi humaniora di Asia pada umumnya.

Hasil studi ini telah memperjelas sejarah bangsa Asia serta kebudayaannya. Sedangkan di kawasan Nusantara, kegiatan filologi terhadap naskah-naskah Nusantara telah mendorong berbagai kegiatan ilmiah yang hasilnya telah dimanfaatkan oleh berbagai disiplin, terutama disiplin humaniora dan disiplin ilmu-ilmu sosial. Semua kegiatan itu telah memenuhi tujuan ilmu filologi, yaitu melalui telaah naskah-naskah dapat membuka kebudayaan bangsa dan telah mengangkat nilai-nilai luhur yang disimpan di dalamnya (Baried dkk, 1985).

Dengan melakukan kegiatan filologi melalui pelestarian dan penggarapan terhadap naskah-naskah kuno, maka akan terungkap nilai-nilai yang terkandung di dalam naskah, sehingga akan terungkap pula sejarah bangsa. Dengan begitu, dapat terbangun kembali karakter dan terbaca pula masa depan suatu bangsa.

Dalam dunia filologi, sedikitnya jumlah filolog atau ahli filologi yang mampu membaca dan menerjemahkan naskah menjadi perhatian penting. Di mana pemuda penerus bangsa saat ini sudah sangat asing dengan bahasa dan aksara yang terdapat dalam naskah. Sedangkan jumlah naskah Nusantara sangatlah banyak. Hal ini sebagaimana yang disampaikan oleh Muhammad Syarif Bando bahwa, profesi filolog di Indonesia tergolong langka. Ia juga menyampaikan bahwa, Indonesia memiliki banyak sekali naskah kuno yang bisa menjadi sumber pengetahuan bahkan penelitian.

Namun naskah kuno tersebut mesti diteliti isinya (Ryanthie, 2017). Oleh karena itu, pembelajaran filologi sangat penting bagi masyarakat luas agar penggarapan atau penelitian terhadap naskah dapat dilakukan oleh banyak orang. Dengan begitu, masyarakat dapat mengetahui dan 
mengungkap isi yang terkandung dalam naskah tersebut.

Adapun tujuan umum dan khusus filologi, di mana tujuan umum filologi adalah: 1) memahami sejauh mungkin kebudayaan suatu bangsa melalui hasil sastranya, baik lisan maupun tulisan; 2) memahami makna dan fungsi teks bagi masyarakat penciptanya; 3) mengungkapkan nilainilai budaya lama sebagai alternatif pengembangankebudayaan.

Sedangkan tujuan khusus filologi yaitu: 1) menyunting sebuah teks yang dipandang mendekati teks aslinya; 2) mengungkap sejarah terjadinya teks dan sejarah perkembangannya; 3) mengungkap resepsi pembaca pada setiap kurun penerimaannya (Baried, dkk 1985).

Dari tujuan-tujuan tersebut dapat ditemukan manfaat pembelajaran filologi, yaitu: a) dengan mengetahui dan memahami kebudayaan suatu bangsa, maka akan terungkap pemikiran-pemikiran orang-orang terdahulu ; b) dapat terungkap kebiasaan masyarakat dan adat istiadat orang-orang terdahulu; c) dapat melestarikan budaya-budaya lama dan mengembangkannya sesuai dengan perkembangan masyarakat pada zamannya; d) dapat terungkap sejarah suatu bangsa yang sesungguhnya; e) terungkapnya proses-proses penulisan dan penyalinan naskah serta kejujuran atau ketidakjujuran para penyalin naskah; f) mengetahui bagaimana pandangan masyarakat yang membaca naskah pada zamannya.

Proses dalam pembelajaran filologi atau penggarapan naskah memerlukan tahapan-tahapan sebagai berikut: 1) melakukan transliterasi terhadap naskah atau penyalinan naskah, yaitu menulis ulang naskah dengan tulisan atau huruf yang berbeda. Dalam kegiatan transliterasi ini dibutuhkan ketelitian dan kecermatan dalam membaca naskah; 2) membandingkan teks yang paling lengkap dan mendekati asli jika terdapat beberapa teks yang sama atau memiliki kemiripan. menerjemahkan teks agar pembaca dapat mengetahui isi naskah tersebut. Dalam proses ini dibutuhkan kemampuan bahasa naskah dalam menerjemahkan teks. mengemukakan nilai kandungan yang terdapat dalam naskah.

Dalam proses ini dibutuhkan kejujuran dalam mengungkap isi naskah tersebut. Dengan mengetahui nilai kandungan yang terdapat dalam naskah, maka akan diketahui kebudayaan, adat istiadat, kebiasaan, serta karakter suatu bangsa. Tanpa mengetahui isi naskah, maka tidak akan diketahui sejarah serta karakter suatu bangsa dari bukti fisik yang otentik.

Sebaliknya, dengan mengetahui isi naskah maka akan terungkap pula sejarah serta karakter suatu bangsa dan berbagai macam ilmu pengetahuan yang ada di dalam naskah yang dapat dijadikan pelajaran untuk kehidupan masa kini. Dengan memahami sejarah Indonesia pada masa lampau, maka arah pembentukan kepribadian bangsa Indonesia akan lebih jelas.

Sebagai contoh, penggalian naskah Nagarakertagama penting bagi 
pembangunan Negara RI di masa kini, karena Nagarakertagama berisi sejarah pembangunan kerajaan Majapahit di masa lampau. Sejarah masa silam merupakan senjata ampuh, yang dapat digunakan untuk menghilangkan hambatan dalam perjuangan kebudayaan untuk membentuk kepribadian serta masa depan (Suryani, 2012).

Hal ini sejalan dengan yang diujarkan oleh Prof. Syarief, Guru Besar Fakultas Ilmu Budaya Unpad sekaligus mantan Ketua Masyarakat Pernaskahan Nusantara (Manassa) Jabar 2003-2008 bahwa, dengan pengungkapan nilai-nilai budaya lama akan bisa memberikan inspirasi kepada masyarakat kini dalam pembinaan karakter bangsa. Ia juga mengungkapkan banyaknya pesan moral yang terkandung di dalam naskah. Pesan moral tersebut di antaranya meliputi pembinaan akhlak hingga ajaran Islam yang berkaitan dengan ekonomi, hukum, maupun kehidupan lainnya (Maulana, 2015).

Kekuatan naskah yang merupakan kajian dalam ilmu filologi mampu membangun moral dan karakter masyarakat suatu bangsa. Hal ini sejalan dengan yang diungkapkan oleh Prof. Syarief tentang Kisah yang tertuang dalam naskah Hikayat Abu Samah (dalam naskah Sunda disebut Abdussomad), itu tentang penerapan hukum. Bagaimana Khalifah Umar bin Khattab yang menerapkan hukum cambuk sampai mati terhadap anaknya sendiri yang melanggar. Inilah gambaran pemimpin yang adil dalam menegakkan hukum (Maulana, 2015).
Kisah religius seperti itu dapat dijadikan oleh tiap negara untuk menjadikan pembelajaran filologi sebagai alat dalam mengungkap karakter suatu bangsa guna dijadikan contoh bagi anak-anak generasi penerus bangsa. Sebagai pembentuk moral dan karakter anak, kisah atau cerita dalam naskah yang telah diterjemahkan dapat dijadikan inspirasi dan panutan bagi anak-anak generasi penerus bangsa, karena dengan membaca kisah atau cerita lama yang terdapat dalam naskah mereka dapat mengetahui sosok nenek moyangnya terdahulu dan bangga terhadap peninggalannya. Dengan semakin banyaknya masyarakat yang memahami proses pembelajaran filologi, maka semakin banyak pula orang yang dapat menggarap suatu naskah, sehingga akan semakin banyak naskah-naskah yang diterjemahkan. Dengan begitu, akan semakin banyak pula berbagai pengetahuan dan pola pikir masyarakat terdahulu yang terungkap serta dapat membina masyarakat saat ini agar menjadi bangsa yang beradab.

\section{Peran Filologi dalam Menyusun Strategi Pembangunan Karakter Bangsa}

Peran filologi dalam
membangun karakter bangsa yaitu dengan cara menggali nilai-nilai moral dan karakter bangsa melalui penelitian atau penggarapan terhadap naskahnaskah, baik yang yang telah diteliti maupun yang belum dianalisis oleh para filolog, beberapa naskah yang telah digarap dan di dalamnya 
dalam Nurrahmah, 2013). Pesan ini tampak dalam kutipan berikut.

...tafakkur menghilangkan anganangan, dan memelihara kelengahan. Tafakkur cerminan fana terhadap dunia, dan menghilangkan kecintaan padanya, dan mewariskan baqa terhadap akhirat, dan mengharapkan perolehannya (Naskah AM, 7)

Pesan moral yang dapat diperoleh dari kutipan tersebut yaitu sebagai manusia yang beriman haruslah selalu mengingat Tuhannya, karena dengan selalu mengingat Tuhannya maka segala tindakan pasti akan terkendali dan tidak menjadi manusia yang ceroboh. Setiap manusia yang beriman kepada Tuhannya juga wajib meyakini bahwa sumber ketenangan hati dan jiwa dengan selalu mengingat kepadaNya. Hal ini sebagaimana yang tertuang dalam Q.S. ar-Ra'du: 28 yang berbunyi, "(yaitu) orang yang beriman dan hati mereka menjadi tenteram dengan mengingat Allah. Ingatlah, hanya dengan mengingat Allah hati menjadi tenteram".

Untuk menjadi manusia unggul harus memiliki keseimbangan dalam ilmu dan amal, karena keduanya akan membawa manusia kepada kebahagiaan hidup dunia dan akhirat. Hal tersebut ditunjukkan dalam kutipan berikut.

Maka bahagialah orang yang hidup dengan memiliki keduanya. Ketahuilah bahwa semua ilmu tanpa amal adalah dosa besar (Naskah AM, 13)

Belakangan ini, banyak orangorang yang berilmu dan memiliki gelar tinggi akan tetapi perilaku dan kata-katanya sangat bertentangan dengan ilmu yang dimilikinya. Sehingga ilmu tersebut seakan tidak ada manfaat bagi dirinya bahkan membuat dirinya tersesat. Sebagaimana pesan moral yang disampaikan dalam kutipan naskah tersebut bahwa amal yang tidak dilatarbelakangi oleh ilmu hanya akan membawa kepada kesesatan. Sedangkan ilmu yang tidak dibarengi dengan amal hanyalah akan menjadi hal yang sia-sia. Untuk itu perlunya keseimbangan antara ilmu dan amal.

Untuk menjadi manusia atau pribadi yang unggul melalui penyelarasan antara zikir, fikir, ilmu, dan amal ini juga akan melahirkan manusia yang ikhlas. Lebih lanjut terdapat dalam kutipan berikut.

...akan tetapi, wahai saudaraku, segalanya tidak akan memberi manfaat kecuali dengan ikhlas, jujur, dan keyakinan yang benar (Naskah AM, 11)

Buah daripada zikir, tafakkur, ilmu, dan amal adalah lahirnya manusia yang berakhlak mulia. Dampaknya adalah akan lahir sebuah tatanan kehidupan masyarakat makmur dan sejahtera, aman, damai, harmonis, yang diselubungi roh Islam yang rahamatan li-al-'alamin. Kejayaan suatu bangsa pasti akan tercapai, karena individu-individu yang unggul pastilah merupakan orang-orang yang amanah dan terpercaya sebagai konsekwensi logis dari kemampuannya menyelaraskan antara zikir, fikir, ilmu, dan amal. Dia adalah asas ketahanan umat, kestabilan negara, kekuasaan, 
kehormatan dan roh keadilan (Baba dalam Nurrahmah, 2013).

Membangun Karakter Bangsa

Melalui Naskah Siksakandang

Karesian (SSK) Koleksi

Skriptorium Naskah Sunda

Buhun Kabuyutan Ciburuy

Salah satu krisis yang dialami bangsa Indonesia saat ini adalah krisis kepemimpinan. Di mana sosok karakter pemimpin bangsa saat ini seakan tidak dapat dijadikan contoh bagi para pemuda penerus generasi bangsa. Maka sangat dibutuhkan sosok yang dapat dijadikan sebagai contoh atau panutan bagi penerus generasi bangsa. Salah satunya yaitu melihat kembali identitas jati diri bangsa Indonesia di masa lalu melalui naskah.

Salah satu naskah yang memberikan konsep figur pemimpin yaitu terdapat dalam naskah SSK yang merupakan salah satu pembahasan yang disajikan oleh Elis Suryani NS dalam makalahnya yang berjudul "Konsep Figur Pemimpin dan Kepemimpinan Yang Terungkap Dalam Skriptorium Naskah Sunda Buhun Kabuyutan Ciburuy pada Simposium Internasional Pernaskahan Nusantara di Yogyakarta. Seorang pemimpin dalam naskah SSK dalam rangka membina dan memimpin bawahannya haruslah memiliki sepuluh pedoman yang disebut dengan Dasa Prasanta. Kesepuluh pedoman tersebut adalah Guna ' bijaksana', Ramah 'bijak, atau bestari', Hook 'kagum', Pésok 'memikat hati', Asih 'sayang, cinta kasih', Karunya 'iba/belas kasih', Mupreruk 'membujuk dan menentramkan hati',
Ngulas 'memuji dan mengoreksi', Nyecep 'membesarkan hati dan memberikan kata-kata yang menyejukkan', Ngala angen 'mengambil hati'.

Jika diuraikan lebih dalam, kesepuluh pedoman tersebut memiliki pesan moral yang dapat dijadikan contoh bagi pemimpin saat ini agar dapat menjadi seorang pemimpin yang mampu mensejahterakan kehidupan dengan rahmat dan ridha Allah SWT. Pesan moral tersebut yaitu seorang pemimpin dalam memberikan perintah harus dapat dipahami manfaat dan kegunaannya oleh bawahannya atau rakyat yang dipimpinnya sehingga tidak terjadi kesalahpahaman.

Seorang pemimpin juga harus seperti orangtua yang bijaksana sehingga dapat menumbuhkan rasa nyaman dalam beraktifitas. Perintah seorang pemimpin dianggap sebagai representasi kekaguman atas prestasi dari orang yang diperintahnya. Selain itu, seorang pemimpin harus mampu mengikat hati bawahannya yang juga merupakan kebanggaan bagi bawahannya.

Perintah dari seorang pemimpin harus dilandasi dengan perasaan kemanusiaan yang penuh getaran kasih serta harus terasa sebagai suatu kepercayaan dari pemimpin kepada yang dipimpinnya. Seorang pemimpin juga harus mampu membujuk dan menentramkan hati yang dipimpinnya. Tidak ada salahnya jika seorang pemimpin memuji pekerjaan atau keberhasilan yang dipimpinnya sebagai penghargaan dan pendorong ke arah yang lebih baik, serta memberi 
perhatian berupa moril maupum materil walaupun hanya sekedar ucapan terima kasih. Dan yang terakhir, seorang pemimpin harus dapat menyambung ikatan silaturahmi yang kental dan harmonis terhadap bawahannya.

Selain karakter baik yang harus dimiliki seorang pemimpin seperti yang telah diuraikan di atas, seorang pemimpin juga harus mampu menjauhi empat karakter negatif, yang dikenal dengan sebutan 'opat paharaman' atau empat hal yang diharamkan, yakni sifat babarian 'mudah tersinggung', pundungan mudah merajuk, humandeuar 'berkeluh kesah', dan kukulutus 'menggerutu' serta menjauhi watak manusia yang membuat kerusakan di dunia. Keempat karakter negatif tersebut haruslah dijauhi oleh seorang pemimpin jika ingin menjadi pemimpin yang berkharisma dan disukai oleh bawahan atau rakyatnya.

Jika masyarakat atau generasi penerus bangsa saat ini mengetahui konsep untuk menjadi manusia yang unggul serta contoh figur pemimpin yang baik, maka akan tercipta masyarakat suatu bangsa yang memiliki karakter yang kuat serta terwujudnya tatanan masyarakat yang harmonis, sejahtera, serta stabilitas negara yang baik. Dengan kata lain, dibutuhkan pembelajaran filologi untuk dapat melakukan penggarapan dan pengkajian terhadap naskah agar dapat mengungkap nilai-nilai serta kandungan yang terdapat dalam naskah. Dengan begitu, kemerosotan moral dan krisis kepemimpinan yang terjadi saat ini dapat teratasi serta dapat menjadi contoh dan pembinaan karakter bagi generasi penerus bangsa untuk dapat membangun kembali karakter suatu bangsa.

\section{SIMPULAN}

Untuk memahami nilai-nilai perilaku manusia yang berhubungan dengan Tuhan Yang Maha Esa, diri sendiri, sesama manusia, lingkungan, dan kebangsaan yang terwujud dalam pikiran, sikap, perasaan, perkataan, serta perbuatan berdasarkan normanorma agama, hukum, tata krama, budaya, dan adat istiadat diperlukan tiga komponen karakter yang baik, yaitu pengetahuan tentang moral, perasaan tentang moral, dan perbuatan moral. Kemerosotan moral dan krisis kepemimpinan yang terjadi saat ini telah menyebabkan lunturnya karakter dan jati diri bangsa Indonesia.

Salah satu penyebab dari kemerosotan moral dan krisis kepemimpinan adalah tidak adanya contoh atau figur yang dapat diikuti dan dijadikan panutan oleh masyarakat generasi penerus bangsa. Agar dapat melihat figur karakter dan jati diri bangsa yang sesungguhnya, maka suatu bangsa haruslah melihat kembali kepada sejarah. Pembelajaran filologi yang kajiannya berupa naskah sangat berperan penting dalam mengembalikan karakter suatu bangsa.

Hal ini dikarenakan ilmu filologi berusaha untuk menemukan teks asli atau mendekati asli dan menempatkannya dalam seluruh aspek sejarah suatu bangsa, yaitu dengan cara melakukan penggarapan terhadap 
naskah. Dengan kata lain, karakter suatu bangsa dapat dibangun dengan cara mengetahui identitas suatu bangsa, dan tidak lepas dari sejarah bangsa yang dapat diungkap melalui proses pembelajaran filologi.

Dengan melakukan kegiatan filologi melalui pelestarian dan penggarapan terhadap naskah-naskah kuno, maka akan terungkap nilai-nilai yang terkandung di dalam naskah, sehingga akan terungkap pula sejarah bangsa.

Dengan begitu, dapat terbangun kembali karakter dan terbaca pula masa depan suatu bangsa. Proses dalam pembelajaran filologi atau penggarapan naskah memerlukan ketelitian dan kecermatan dalam membacanya. Hal ini dikarenakan jika terjadi kelalaian atau kecerobohan dalam membaca naskah, maka akan terjadi perubahan dalam proses transliterasi dan terjemahan naskah sehingga akan merubah isi naskah tersebut.

Selain itu, dalam mengungkapkan isi naskah dibutuhkan kejujuran dari peneliti. Hal ini dikarenakan jika peneliti tidak jujur dalam mengungkapkan isi naskah, maka akan terjadi ketidaksesuaian makna yang terkandung dalam naskah dengan apa yang diungkapkan.

Peran filologi dalam membangun karakter bangsa yaitu dengan cara menggali nilai-nilai moral dan karakter bangsa melalui penelitian atau penggarapan terhadap naskahnaskah, baik yang yang telah diteliti maupun yang belum dianalisis oleh para filolog. Dengan semakin banyaknya masyarakat yang memahami proses pembelajaran filologi, maka semakin banyak pula orang yang dapat menggarap suatu naskah, sehingga akan semakin banyak naskah-naskah yang diterjemahkan.

Dengan begitu, akan semakin banyak pula berbagai pengetahuan dan pola pikir masyarakat terdahulu yang terungkap serta dapat membina masyarakat saat ini agar menjadi bangsa yang beradab serta menjadi solusi bagi permasalahan rakyat saat ini dalam menghadapi krisis moral dan krisis kepemimpinan.

\section{DAFTAR PUSTAKA}

Baried. (1985). Pengantar Teori Filologi. Jakarta: Pusat Pembinaan dan Pengembangan Bahasa Departemen Pendidikan dan Kebudayaan

Citra, Y. (2012). Pelaksanaan Pendidikan Karakter dalam Pembelajaran. E-JUPEKhu (Jurnal Ilmiah Pendidikan Khusus), 1 (1), Januari 2012.

Johansyah. (2011). Pendidkan Karakter dalam Islam: Kajian dari Aspek Metodologis. Jurnal Ilmiah ISLAM FUTURA, XI (1), Agustus 2011

Kartiningrum, E., D. (2015). Panduan Penyusunan studi literatur. Mojokerto: Lembaga Penelitian dan Pengabdian Masyarakat Politeknik Kesehatan Majapahit.

Kementerian Agama RI. (2010). AlQuran Terjemah dan Tafsir Perkata. Bandung: Pondok Yatim Al Hilal.

Maulana, A. (2015). Naskah Kuno Bisa Jadi Inspirasi Pembinaan 
Karakter Masa Kini. Unpad.ac.id

Maunah, B. (2015). Implementasi Pendidikan Karakter dalam Pembentukan Kepribadian Holistik Siswa. Jurnal Pendidikan Karakter, Tahun V, No. 1, April 2015.

Nurrahmah. (2013). Konsep Manusia Unggul: Kajian Atas Naskah Anis Al-Muttaqin. Jakarta: Jurnal Penelitian Lektur dan Khazanah Keagamaan, 11 (1), Juni 2013.

Ryanthie, S. (2017). Hanya Punya 30 Ahli, Indonesia Butuh Ribuan Filolog. Harianjogja.com.

Sudibyo, (2007). Kembali ke Filologi: Filologi Indonesia dan Tradisi Orientalisme. Jurnal Humaniora, 19 (2), Juni 2007.

Suryani, E. (2012). Konsep Figur Pemimpin dan Kepemimpinan yang Terungkap dalam Skriptorium Naskah Sunda Buhun Kabuyutan Ciburuy. Yogyakarta: Makalah Simposium Internasional Pernaskahan Nusantara.

Yusuf, C., F. (2013). Kritik Atas The Moral Landscape: How Science an Determine Human Values. Jakarta: Jurnal Penelitian Lektur dan Khazanah Keagamaan, 11, (1), Juni 2013. 